\title{
Labor Division in Melipona compressipes fasciculata Smith (Hymenoptera: Apidae: Meliponinae)
}

\author{
Katia M. Giannini ${ }^{1}$ \\ ${ }^{1}$ Departamento de Biologia, F. F. C. L. R. R, USP, Av. Bandeirantes, 3900, \\ 14040-901, Ribeirão Preto, SP.
}

An. Soc. Entomol. Brasil 26(1): 153-162 (1997)

Divisão de Trabalho em Melipona compressipes fasciculata Smith (Hymenoptera: Apidae: Meliponinae)

\begin{abstract}
RESUMO - A divisão de trabalho em Melipona compressipes fasciculata Smith foi analisada e comparada com outras abelhas eusociais - Meliponini e Trigonini. Os resultados mostraram que existe uma sequência de atividades similar a outros meliponíneos já estudados, a saber: "grooming", trabalho com cerume, construção de células, limpeza da colônia, participação no processo de aprovisionamento e oviposição (POP), desidratação de néctar, ventilação, vedação de frestas, recepção de néctar, guarda e forrageamento.
\end{abstract}

PALAVRAS-CHAVE: Insecta, Meliponini, abelhas sem ferrão, divisão de trabalho, abelhas eusociais.

ABSTRACT - Labor division in the stingless bee Melipona compressipes fasciculata Smith was analyzed and compared with that of other eusocial bees Meliponini and Trigonini. The results showed a sequence of activities which was similar to that of other stingless bees already studied, such as: grooming; cerumen work; cell construction; cleaning; the colony; provisioning and oviposition process; ventilation; enclosure gap; nectar reception; and foraging.

KEY WORDS: Insecta, Meliponini, stingless bees, division of labor, eusocial bees.

The existence of physical and temporal castes is one of the most complex and important factors in the social structure of insect colonies (Oster \& Wilson 1978). The physical castes include a queen, a small number of males, and the numerically predominant worker caste. The temporal caste consists of temporal labor division in which there is an ontogenetic sequence of activities performed during the workers' lifetime.

In the earliest studies on labor division of honeybees, it was reported that worker activities presented a temporal basis (Butler 1609 apud Winston \& Fergusson 1986, Donhoff 1855 apud Winston \& Fergusson 1986). Further research analyzed the flexibility in temporal labor division and the underlying glandular basis for tasks performance (Rösch 1925 apud Winston \& Fergusson 1986, Ribbands 1952, Lindauer 1953, Sekiguchi \& Sakagami 1966). Recent investigation has involved the colony-level factors which try to determine the reasons why bees perform duties at different times (Free 1961, Kolmes 1985, Winston \& Fergusson 1985, among others). 
The typical labor division in eusocial bees proceeds in the following sequence: callow, nursing, household, and foraging (Sakagami 1982). However, there is considerable flexibility concerning the age-related trend of activities so that the tasks sequence can be adjusted in relation to the colony external or internal requirements.

Some of the research on labor division in Meliponinae shows the sequence of tasks performed during the workers' lifetime (Bassindale 1955, Kerr \& Santos Neto 1956, Hebling et al. 1964, Darchen 1969). More recently, research has described a temporal sequence of labor division in Melipona bicolor bicolor Lepeletier (Bego 1983), Melipona favosa Fabricius (Sommeijer 1984), Frieseomelitta languida Moure \& Camargo (Ribeiro 1989), Nannotrigona (Scaptotrigona) postica Latreille (Simões \& Bego 1991), Tetragonisca angustula angustula Latreille (Grosso 1993) and Plebeia remota Holmberg (van Benthem et al. 1995), among others.

This is a contribution to add more information on the activity of individual workers in relation to the temporal tasks sequence of Melipona compressipes fasciculata Smith, comparing the results with other Meliponinae species.

\section{Materiais and Methods}

This study was conducted at Ribeirão Preto, S.R, Brazil, from September to December 1991. Two colonies of M. compressipes fasciculata from São Luís, MA, were used. Colonies were manipulated only for the introduction of marked workers. A marked cohort of 111 newly emerged workers was introduced into an observation hive. The cohort was obtained by removing combs from another hive so that bees could emerge overnight in an incubator at $28^{\circ} \mathrm{C}$ to be later introduced into the hive $1-2 \mathrm{~h}$ after marking. During 14 consecutive days all the workers which emerged were individually marked. These workers were up to $24 \mathrm{~h}$ old. The general conditions of the colony were measured based on the number of brood combs and on the number of pollen and honey pots. The 1st observation was carried out in the beginning of the experiment and the 2nd when the experiment was finished (Table 1).

Observation was carried out in both extra and oviposition periods - i.e., $8 \mathrm{~h}$ of daily observation. The marked workers were recorded as performing one or more tasks through individual observations.

Table 1. General conditions of Melipona compressipes fasciculata colonies.

\section{Date}

\begin{tabular}{lcc}
$\begin{array}{l}\text { Colony } \\
\text { Conditions }\end{array}$ & Sept. 27 1991 & Dec. 20 1991 \\
\cline { 2 - 3 } $\begin{array}{l}\text { Number of pollen } \\
\text { pots }\end{array}$ & 5 (open) & 6 (open) \\
& 3 (closed) & 12 (closed) \\
$\begin{array}{l}\text { Number of honey } \\
\text { pots }\end{array}$ & 5 (open) & 6 (open) \\
& 14 (closed) & 31 (closed) \\
$\begin{array}{l}\text { Number of young } \\
\text { brood combs }\end{array}$ & 3 & 2 \\
$\begin{array}{l}\text { Number of combs } \\
\text { with immature } \\
\text { in different phases } \\
\text { of development }\end{array}$ & 4 & 2 \\
\hline
\end{tabular}

The activities performed by workers as well as queen/worker interactions were observed according to the following classification: Grooming $=\mathrm{a}$ bee cleans any parts of its body with its mouthparts or legs; Cerumen work = removal of cerumen from old brood cells, construction of support pillars, food pots and involucrum; Cell construction = mainly mandibular "manipulation" of cell parts or working inside the cell; Provisioning and oviposition process $(\mathrm{POP})=$ participation in the provisioning and oviposition process of brood cells (Arousal 
stage, food discharge, worker oviposition and cell operculation); Cleaning $=$ manipulation of waste material and pieces of cocoon that are carried out of the colony; Enclosure gap = with cerumen and mud; Ventilation $=$ wing beatings; Trophailaxis $(\mathrm{Tr})=$ food exchange from worker to queen; Food reception $=$ from worker to worker; Beg food (B) = from queen to worker; Nectar reception $=$ from worker to worker; Foraging $=$ collection of food and material for nest construction; Insertion (I) $=$ forebody insertion into cell; Escape $(\mathrm{E})=$ worker escapes when the queen approaches; Advance $(\mathrm{AD})=$ simple advance (a worker darts on the queen); Advance-back $(\mathrm{AB})=$ the worker performs advance and back movements in the presence of the queen.

\section{Results and Discussion}

The average longevity observed for $M$. compressipes fasciculata was one of 42.5 (Ito 80 days) (Fig. 1). According to Sakagami \& Fukuda (1968), the type of survival curve is directly correlated with the division of labor.
Convex curves are found in species with low mortality during the initial phases of life. The high mortality was observed to be true of age brackets in which workers became foragers.

In the other species of Meliponinae bees the following longevities were recorded: Plebeia (Friesella) schrottkyi Friese, 30.1 days (Camillo-Atique 1977), F. languida, 33.3 days (Ribeiro 1989), M. bicolor bicolor, 44.0 days (Bego 1983), N. (Scaptotrigona) postica for three colonies estudied, 26.3 days, 39.5 days and 32.9 days (Simões \& Bego 1991), M.favosa, 40.0 days (Sommeijer 1984) and Melipona scutellaris Latreille, 27.4 and 34.5 days (H. H. Oliveira \& A. Kleinert-Giovannini, pers. inf.) for two different colonies observed. The internal conditions of the colony, observations in different periods of the year, and different morphological and physiological conditions among the species are probably responsible for these variations.

When analyzing our data according to the workers' age sequence, the main aspects described below were observed: the cerumen work is one of the 1st activities performed by workers in $M$. compressipes fasciculata. The

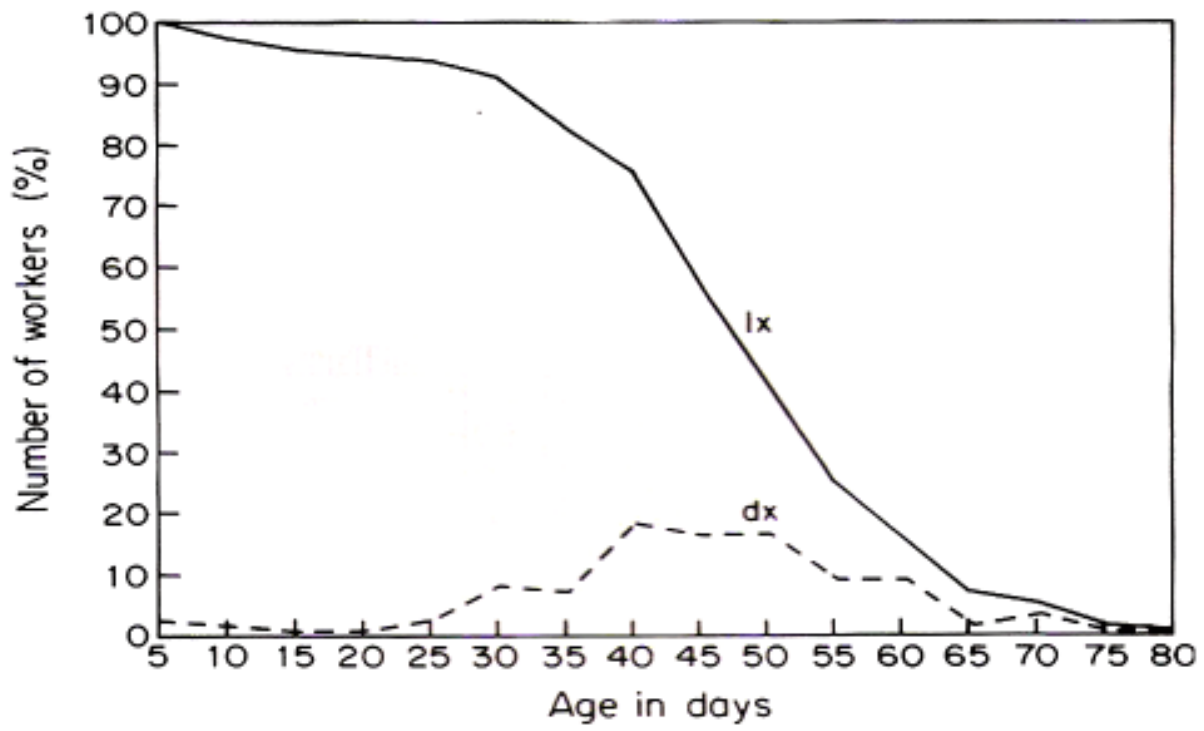

Figure 1. Survival curve (lx) and mortality curve (dx) for workers of Melipona compressipes fasciculata. 


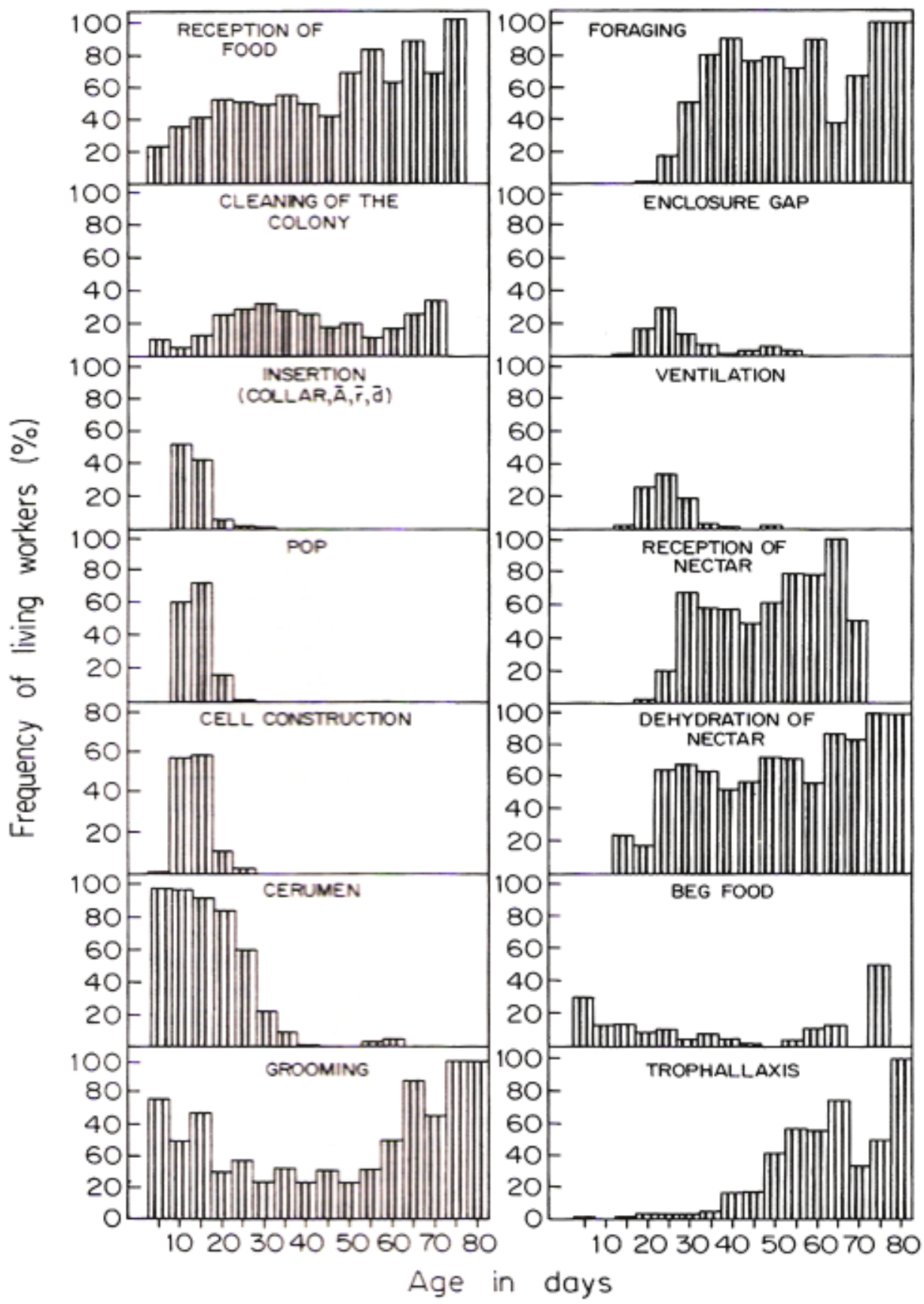

Figure 2. Frequency of workers of Melipona compressipes fasciculata engaged in various activities according to respective age in brackets. 
grooming task and colony cleaning are activities that overlap almost completely. Duties as reception, nectar dehydration and foraging are performed only after the bees have participated in the cell construction and oviposition process. Trophailaxis and food reception occur ali during the workers' lives. It is important to consider that trophallaxis is more conspicuous when bees are older, and that nectar reception starts when they are young. Beg food is performed throughout the bees' lifetime (Fig.2).

The activities observed by different authors do not agree with those defined for $M$. compressipes fasciculata, which makes the comparison of results difficult. It is important to emphasize the fact that labor division is dynamic and that it varies with species, colonies, and colonial needs (Sekiguchi \& Sakagami 1966, Simões \& Bego 1979,1991, Bego
1983). Thus, the internal conditions related to the number of workers available to perform each task, the queen's laying rate, stored food, the age of colony members, etc. are important factors in stablishing such dynamic. External conditions such as seasonality (Ceccato 1970, H. H. Oliveira \& A. Kleinert-Giovannini pers. inf), availability of food resources and nest construction material, etc. can also influence colony dynamic.

A important point is the overlap of duties. A determined worker can perform more than one activity at the same time in all the species observed. The frequency of bees' performing different activities throughout their lives (Fig. 3) were: $99.1 \%$ worked with cerumen; $76.6 \%$ worked in cell construction; $52.3 \%$ participated in the oviposition process; $95.5 \%$ did grooming; $75.7 \%$ were involved in the colony cleaning; $0.9 \%$ worked with mud; $5.4 \%$ were

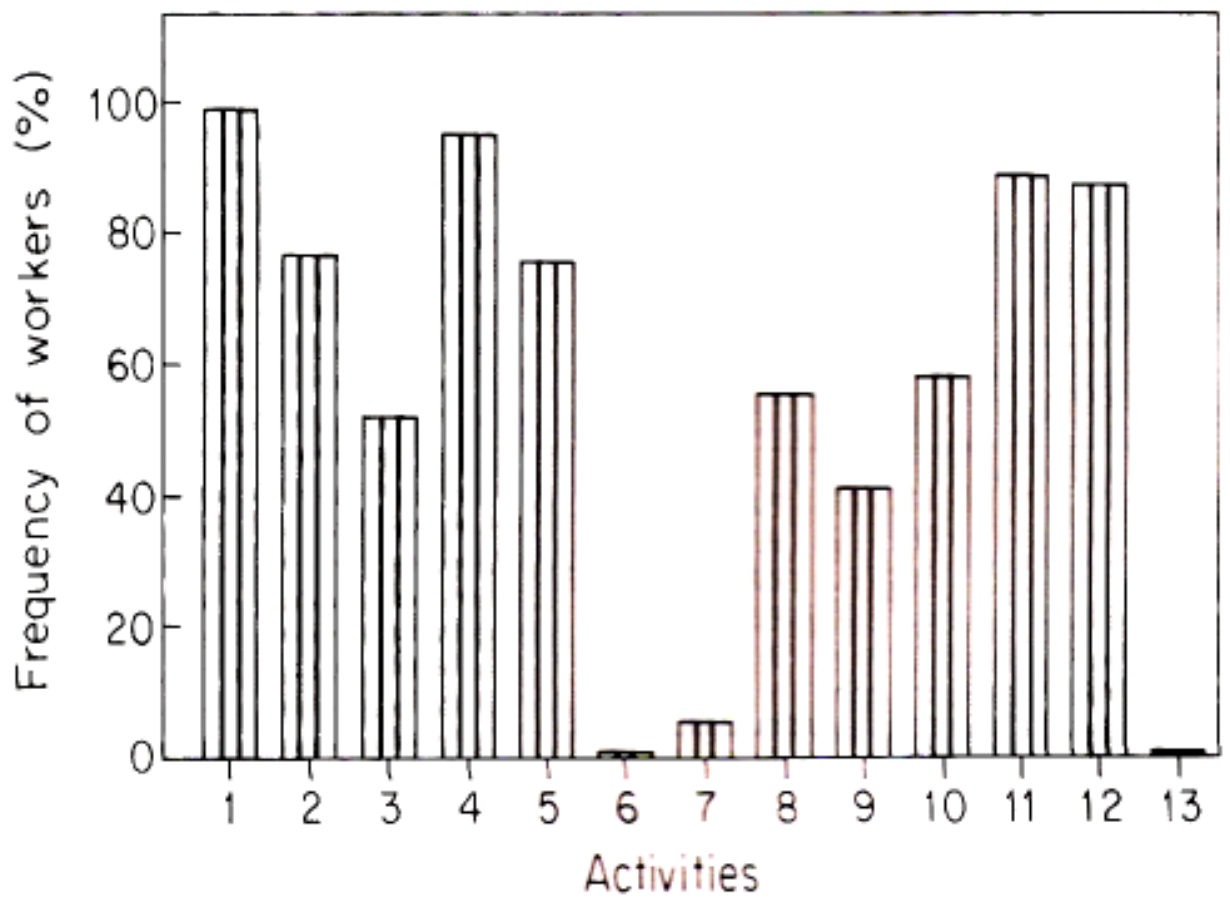

Figure 3. Frequency of workers of Melipona compressipes fasciculata performing different activities in the colony. $1=$ cerumen; 2 = cell construction; $3=$ oviposition process; $4=$ grooming; $5=$ colony cleaning; $6=$ mud work; $7=$ resin work; $8=$ ventilation; $9=$ enclosure gap; $10=$ néctar reception; $11=$ nectar dehydration; 12 = foraging; and $13=$ guarding. 


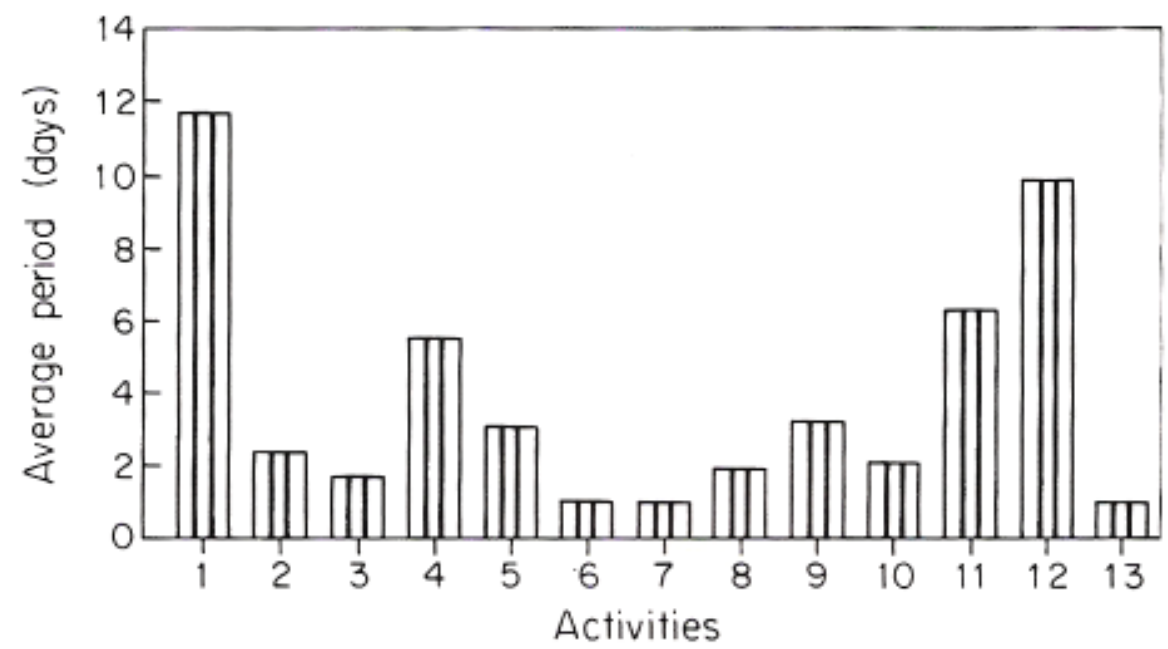

Figure 4. Average period (in days) for each activity performed in Melipona compressipes fasciculata. $1=$ cerumen; $2=$ cell construction; $3=$ oviposition process; $4=$ grooming; $5=$ colony cleaning; $6=$ mud work; $7=$ resin work; $8=$ ventilation; 9 = enclosure gap; $10=$ nectar reception; $11=$ nectar dehydration; $12=$ foraging; and $13=$ guarding.

seen working with resin; $55.9 \%$ ventilated the nest; $41.4 \%$ performed the enclosure gap of the colony; $58.6 \%$ performed nectar recep- tion; $90.1 \%$ dehydrated nectar; $88.3 \%$ worked as foragers and $0.9 \%$ performed the guarding task. The M..bicolor bicolor data (Bego 1983)

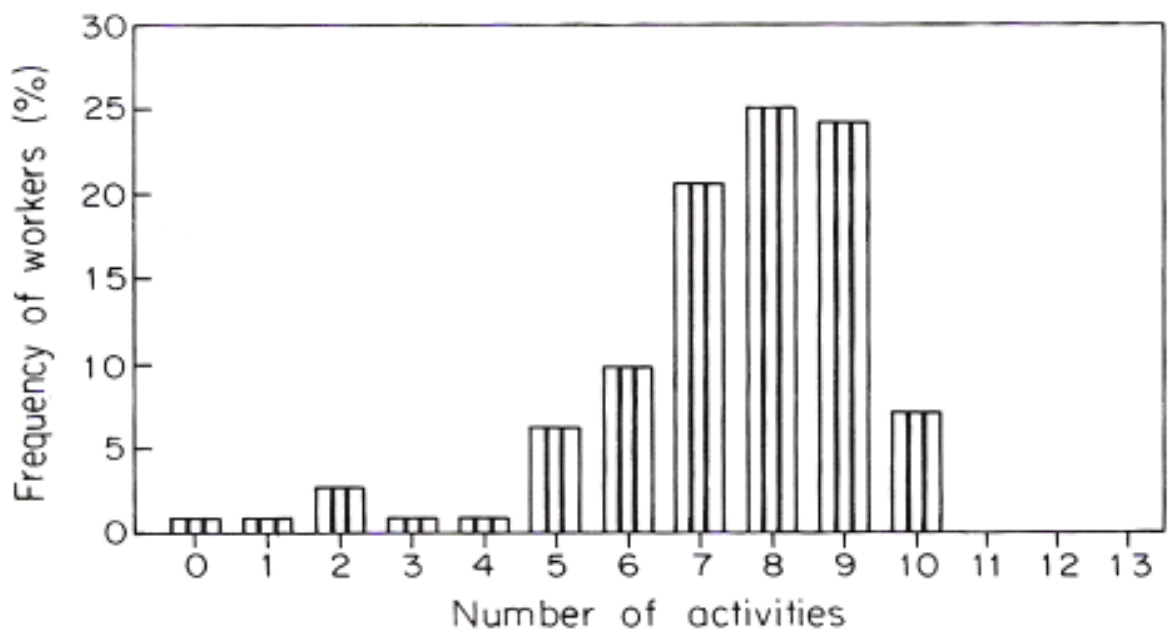

Figure 5. Frequency of workers in relation to the number of activities performed in Melipona compressipes fasciculata. $\mathrm{O}=$ no activity; $1=$ cerumen; $2=$ cell construction; $3=$ oviposition process; $4=$ grooming; $5=$ colony cleaning; $6=$ mud work; $7=$ resin work; $8=$ ventilation; 9 = enclosure gap; $10=$ nectar reception; $11=$ nectar dehydration; $12=$ foraging; and 13 = guarding. 
are different when compared with those of $M$. compressipes fasciculata as to colony cleaning. N. (Scaptotrigona) postica (Simões \& Bego 1991), M. bicolor bicolor (Bego 1983) and F. schrottkyi (Camillo-Atique 1977) present lower frequency of workers as to foraging activity differently from $M$. compressipes fasciculata. As to guarding, the species above, including F. languida (Ribeiro 1989), presented higher frequency than that observed for $M$. compressipes fasciculata.

The average period for each activity performed by workers (Fig. 4) indicated that the duration of cerumen work was of ca. $12 \mathrm{~d}$; cell construction $=2 \mathrm{~d}$; oviposition process $=2 \mathrm{~d}$; grooming $=6 \mathrm{~d}$; colony cleaning $=3 \mathrm{~d}$; mud work $=1 \mathrm{~d}$; resin work $=1 \mathrm{~d}$; ventilation $=2$ $\mathrm{d}$; enclosure gap $=3 \mathrm{~d}$; nectar reception $=2$ $\mathrm{d}$; nectar dehydration $=6 \mathrm{~d}$; foraging $=10 \mathrm{~d}$ and guarding $=1$ day. In $N$. (Scaptotrigona) postica (Simões \& Bego 1991) obtained similar results, except for nectar dehydration.

As to the frequency of workers of $M$. compressipes fasciculata related to the num- ber of duties carried out (Fig. 5), most of them performed from 7 to 9 activities, $20.7 \%$ (7), $25.2 \%$ (8) and $24.3 \%$ (9). Only a small number of bees did not perform any duties and, finally, no bees carried out all the activities. In $\mathrm{M} b i$ color bicolor (Bego 1983), most bees performed from 4 to 6 tasks, $26.0 \%$ (4), $36.0 \%$ (5) and $27.0 \%$ (6). Inherwork, Bego (1983) considered a total of 7 activities. In addition, all marked bees performed more than one duty. Only $1.5 \%$ performed ali the tasks. As to F. languida (Ribeiro 1989), most bees did from 4 to 6 duties, $22.5 \%$ (4), $25.0 \%$ (5) and $17.5 \%$ (6). $1.0 \%$ of the total number of workers did not perform any tasks and $2.0 \%$ did all duties.

The frequency of queen/worker interactions in relation to workers' age in the extraoviposition period showed that escape occurred until $60 \mathrm{~d}$, simple advance until $45 \mathrm{~d}$ and advance-back until $40 \mathrm{~d}$. The highest frequency occurred during the age period in which the workers participated in the oviposition process, except for the escape behavior that

Table 2. Frequency (\%) of workers that performed interactions with the queen in the extra-oviposition period in Melipona compressipes fasciculata.

\begin{tabular}{|c|c|c|c|c|c|c|c|}
\hline \multirow[b]{2}{*}{ Age (days) } & \multicolumn{7}{|c|}{ Interactions } \\
\hline & $\mathrm{E}$ & $\mathrm{AD}$ & $\mathrm{AB}$ & I & $\operatorname{Tr}$ & B & $\mathrm{T}$ \\
\hline $0-5$ & 10.8 & 0.9 & 49.6 & 0.9 & 3.6 & 20.7 & 111 \\
\hline $6-10$ & 4.6 & 12.0 & 83.3 & 17.6 & 12.0 & 13.9 & 108 \\
\hline $11-15$ & 7.6 & 31.1 & 80.2 & 8.5 & 2.8 & 9.4 & 106 \\
\hline $16-20$ & 12.4 & 29.5 & 63.8 & 2.9 & 7.6 & 2.9 & 105 \\
\hline $21-25$ & 5.8 & 15.4 & 42.3 & 0 & 7.7 & 2.9 & 104 \\
\hline $26-30$ & 6.9 & 7.9 & 14.9 & 0 & 1.0 & 0 & 101 \\
\hline $31-35$ & 8.7 & 5.4 & 3.3 & 0 & 2.2 & 1.1 & 92 \\
\hline $36-40$ & 1.2 & 3.6 & 1.2 & 0 & 0 & 0 & 84 \\
\hline $41-45$ & 4.7 & 1.6 & 0 & 0 & 0 & 0 & 64 \\
\hline $46-50$ & 2.2 & 0 & 0 & 0 & 0 & 0 & 46 \\
\hline $51-55$ & 0 & 0 & 0 & 0 & 0 & 0 & 28 \\
\hline $56-60$ & 5.6 & 0 & 0 & 0 & 0 & 0 & 18 \\
\hline
\end{tabular}

$\mathrm{E}=$ escape $\mathrm{AD}=$ advance $\mathrm{AB}=$ advance-back; $1=$ insertion; $\mathrm{Tr}=$ trophallaxis $; \mathrm{B}=$ beg food. $\mathrm{T}=$ total number of living workers in each age bracket. 
was very intensive until the last days of the bees' lives. Forebody insertion in collared cells occurred until $20 \mathrm{~d}$, and was coincident to the age of the workers which participated in the oviposition process. Trophallaxis and beg food occurred until $35 \mathrm{~d}$; the highest fre- quency in relation to the fonner was from 6 to $10 \mathrm{~d}$ of iife and to the later it was from 1 to 5 $\mathrm{d}$ of the workers' lives (Table 2). In general, results showed that the behavior related to queen/worker interactions were not limited to 1 younger workers.

Table 3. Frequency (\%) of workers that performed interactions with the queen in the oviposition process in Melipona compressipes fasciculata.

\begin{tabular}{|c|c|c|c|c|c|c|c|}
\hline \multirow[b]{2}{*}{ Age (days) } & \multicolumn{7}{|c|}{ Interactions } \\
\hline & $\mathrm{E}$ & $\mathrm{AD}$ & $\mathrm{AB}$ & I & $\operatorname{Tr}$ & B & $\mathrm{T}$ \\
\hline $0-5$ & 0 & 0 & 15.3 & 0 & 0 & 0 & 111 \\
\hline $6-10$ & 0.9 & 2.8 & 70.4 & 39.8 & 2.8 & 4.6 & 108 \\
\hline $11-15$ & 0 & 4.7 & 45.3 & 41.5 & 3.8 & 6.6 & 106 \\
\hline $16-20$ & 0 & 1.0 & 11.4 & 6.7 & 1.0 & 0 & 105 \\
\hline $21-25$ & 0 & 0 & 0 & 0 & 0 & 0 & 104 \\
\hline $26-30$ & 0 & 0 & 0 & 1.0 & 0 & 0 & 101 \\
\hline $31-35$ & 0 & 0 & 2.2 & 0 & 0 & 0 & 92 \\
\hline
\end{tabular}

$\mathrm{E}=$ escape $\mathrm{AD}=$ advance $\mathrm{AB}=$ advance-back $; 1=$ insertion $; \mathrm{Tr}=$ trophallaxis $; \mathrm{B}=$ beg food. $\mathrm{T}=$ total number of living workers in each age bracket.

The frequency of interactions in relation to workers' age in the oviposition period shows that escape occurs in the interval from 6 to $10 \mathrm{~d}$, simple advance from 6 to $20 \mathrm{~d}$, advance-back until $35 \mathrm{~d}$, forebody insertion into the cell from 6 to $30 \mathrm{~d}$, beg food from 6 to 15 $\mathrm{d}$, and trophallaxis from 6 to $20 \mathrm{~d}$ (Table 3).

Our results showed that in $M$. compressipes fasciculata, the POP tasks comprise mixed activities, i.e., the bees did notperform continuosly the same kind of duty. Being so, they performed these tasks without presenting any kind of constancy in a particular work. As for labor division in general, however, M. compressipes fasciculata data showed a partern similar to that of several other stingless bees studied up to now related to the sequence of activities: grooming, cerumen work, cell construction, colony cleaning, participation in the provisioning and oviposition process (POP), nectar dehydration, ventilation, enclosure gap, nectar reception, guarding and fora- ging (Kerr \& Santos Neto 1956, Hebling et al. 1964, Darchen 1969, Russo 1976, Camillo-Atique 1977, Bego 1983, Sommeijer 1984, Ribeiro 1989, Simões \& Bego 1991, Grosso 1993 and van Benthem et al. 1995).

\section{Acknowledgments}

This research is part of a M. Sc. thesis. Special thanks are given to Dra. Luci R. Bego for her advise and to CNPq, which provided financial support.

\section{Literature Cited}

Bassindale, R. 1955. The biology of the stingless bee Trigona (Hypotrigona) gribodoi Magretti (Meliponinae). Proc. Zool. Soc.Lond. 125:49-62.

Bego, L. R. 1983. On some aspects of in $M e$ lipona bicolor bicolor Lepeletier (Hyme- 
noptera, Apidae, Meliponinae). Rev. Bras. Entomol. 27:211-224.

Ceccato, S. 1970. Divisão de trabalho entre operárias de Melipona rufiventris flavolineata Friese (Hym., Apoidea). Tese de mestrado, USP, São Paulo, 30p.

Camillo-Atique, C. 1977. Estudo da variabilidade etológica de Friesella incluindo a caracterização de espécies crípticas (Hym., Meliponinae). Tese de doutorado, USP, Ribeirão Preto, 203p.

Darchen, R. 1969. Sur la biologie de Trigona (Apotrigona) nebulata Komiensis Cock. I. Biol.Gabonica 5:151-183.

Free, J. B. 1961. Hypopharyngeal gland development and division of labour in honey-bee (Apis meilifera L.) colonies. Proc. R. Entomol. Soc. London Ser. A 36: 5-8.

Grosso, A. F. 1993. Estudos bionômicos em Tetragonisca angustula angustula Latreille, 1811 (Hymenoptera, Apidae, Meliponinae). Tese de mestrado, USP, Ribeirão Preto, $174 \mathrm{p}$,

Hebling, N. J.,W. E. Kerr \& F. S. Kerr. 1964. Divisão de trabalho entre operárias de Trigona (Scaptotrigona) xanthotricha Moure. Pap. Avuls. Depto. Zool. Secret. Agr., São Paulo 16: 115-127.

Kerr, W. E. \& G. R. Santos Neto. 1956. Contribuição para o conhecimento da bionomia dos Meliponini. 5. Divisão de trabalho entre as operárias de Melipona quadrifasciata quadrifasciata Lep. Ins. Soc. 3: 423-130.

Kolmes, S. A. 1985. A quantitative study of the division of labour among worker honey bees. Z. Tierpsychol. 68:287-302.
Lindauer, M. 1953. Division of labour in the honeybee colony. Bee Wld. 34: 63-84.

Oster, G. F. \& E. O.Wilson. 1978. Caste and Ecology in the Social Insects. Princeton, Princeton University Press, 342p.

Ribbands, C. R. 1952. Division of labour in the honeybee community. Proc. Roy. Soc. 140:32-43.

Ribeiro, M. F. 1989. Estudos ecoetólogicos em Frieseomelitta languida, Moure \& Camargo, in litt (Hymenoptera, Apidae, Meliponinae).Tese de mestrado, USP, São Paulo, 129p.

Russo, V. E. G. de 0.1976. Divisão de trabalho entre operárias de Trigona (Geotrigona) sp. Ciênc. e Cult. 28: 343-347.

Sakagami, S. F. 1982. Stingless bees, p. 361 423. In H. R. Hermann (ed.). Social insects. Academic Press, NewYork, 459p.

Sakagami, S.F. \& H. Fukuda. 1968. Life tables for worker honeybee. Res. Popul. Ecol. 10:127-139.

Sekiguchi, K. \& S. F. Sakagami. 1966. Struture of foraging population and related problems in the honeybee, with consideration on the division of labour in bee colonies. Hokkaido Agr. Exp. Sta. Rep. 69:1-65.

Simões, D. \& L. R. Bego. 1979. Estudo da regulação social em Nannotrigona (Scaptotrigona) postica Latreille, em duas colónias (normal e com rainhas virgens), com especial referência ao polietismo etário (Hym., Apidae, Meliponinae). Bol. Zool., Univ. S. Paulo 4: 89-97. 
Simões, D. \& L. R. Bego. 1991. Division of labor, average life span and life table in Nannotrigona (Scaptotrigona) postica Latreille (Hymenoptera, Apidae, Meliponinae). Naturalia 16:81-97.

Sommeijer, M. J. 1984. Distribuition of labour among workers of Melipona favosa F.: age-polyethism and worker oviposition. Ins.Soc.31:171-184.

van Benthem, F. D. J., V. L. ImperatrizFonseca \& H. H. W. Velthuis. 1995. Biology of the stingless bee Plebeia remota (Holmberg): observations and evolutionary implications. Ins. SAoc. 42: 71-78.

Winston, M. L. \& L. A. Fergusson. 1985.

The effect of worker loss on temporal caste structure in colonies of the honey bee (Apis mellifera L.). Can. J. Zool. 63: 777-780.

Winston, M. L. \& L. A. Fergusson. 1986. The influence of the amount of eggs and larvae in honey bee (Apis meilifera L.) colonies on temporal division of labor. J. Apicult.Res.25:23 8-241.

Received 08/V/96. Accepted 19/111/97. 